\title{
Preparation and application of silver oxide/sawdust nanocomposite for Chromium (VI) ion removal from aqueous solutions using column system
}

\author{
Ostovar F. ${ }^{1,2}$, Ansari R. ${ }^{2,}{ }^{*}$ and Moafi H.F. ${ }^{2}$ \\ ${ }^{1}$ Academic Center, Education Culture and Research, Environmental Engineering group, Rasht, Iran \\ 2Department of Chemistry, Faculty of Science, University of Guilan, Rasht, Iran \\ Received: 20/12/2016, Accepted: 20/08/2017, Available online: 18/10/2017 \\ *to whom all correspondence should be addressed: e-mail: ransari271@guilan.ac.ir
}

\begin{abstract}
This study describes the removal of $\mathrm{Cr}$ (VI) ions from aqueous solutions using silver oxide/sawdust nanocomposite $\left(\mathrm{Ag}_{2} \mathrm{O} / \mathrm{SD} \mathrm{NC}\right)$ that was prepared using the chemical precipitation method. Scanning Electron Microscopy (SEM), X-ray Diffraction (XRD) and Fourier Transform Infrared Spectroscopy (FT-IR) techniques were used for characterization of $\mathrm{Ag}_{2} \mathrm{O} / \mathrm{SD} \mathrm{NC}$. The effect of various parameters such as feed solution $\mathrm{pH}(2,6$, and 10$)$, influent concentration of Chromium (VI) $(25-100 \mathrm{mg} / \mathrm{L})$, flow rate $(1-5 \mathrm{~mL} / \mathrm{min})$ and bed depth $(4-12 \mathrm{~cm})$ on breakthrough curves (BTC) were investigated. Three wellknown column adsorption kinetics models including Thomas, Adams-Bohart and Bed Depth Service Time (BDST) models were applied to fitting the column experimental data. Based on Thomas model, the equilibrium adsorption reached $13.41 \mathrm{mg} / \mathrm{g}$ when a $\mathrm{Cr}(\mathrm{VI})$ polluted solution with influent concentration of $25 \mathrm{mg} / \mathrm{L} \mathrm{Cr}(\mathrm{VI})$ passed through the column with a flow rate of $2 \mathrm{~mL} / \mathrm{min}$. Desorption studies reveal that recovery of uploaded $\mathrm{Cr}$ (VI) from the $\mathrm{Ag}_{2} \mathrm{O} / \mathrm{SD} \mathrm{NC}$ adsorbent or exhausted column regeneration can readily be achieved using a dilute solution of $\mathrm{NaOH}$ $(0.01 \mathrm{M})$ as eluent. This study indicated that the $\mathrm{Ag}_{2} \mathrm{O} / \mathrm{SD}$ NC can be used as an effective, efficient and environmentally friendly adsorbent for the removal of $\mathrm{Cr}$ (VI) ions from water resources.
\end{abstract}

Keywords: Removal, $\mathrm{Cr}(\mathrm{VI})$, Silver oxide/sawdust Nanocomposite, Column system

\section{Introduction}

The presence of toxic heavy metals in water creates serious health and environmental hazards. Hence, significant research activities have been aimed to remove heavy metal ions from water resources. Chromium stands as one of the most toxic and carcinogenic chemical element, has been commonly used in a number of industrial processes, such as leather tanning, cement industries, production of steel and other metal alloys, electroplating, metal polishing, photographic material and corrosive paints (Badruddoza et al., 2013; Li et al., 2006; Malkoc et al., 2006). Cr (VI) is a powerful carcinogenic agent that modifies the DNA transcription process causing important chromosomal aberrations. Due to high toxicity and bioaccumulation of $\mathrm{Cr}$ (VI), the removal of $\mathrm{Cr}$ (VI) ions from contaminated aqueous solution is the great importance. Based on the World Health Organization (WHO), maximum permissible concentration of $\mathrm{Cr}(\mathrm{VI})$ ions in drinking water has been reported $0.01 \mathrm{mg} / \mathrm{L}$, whereas US Environmental Protection Agency (EPA) has set the maximum contaminate level for $\mathrm{Cr}$ (VI) at $0.1 \mathrm{mg} / \mathrm{L}$ (Lv et al., 2011; Wang et al., 2013).

Various methods for removing of $\mathrm{Cr}$ (VI) have been developed, such as cyanide treatment, electro-chemical precipitation (Liu et al., 2011), reverse osmosis, adsorption (Bayramoglu and Arica, 2011), and ion exchange (Sardohan et al., 2010). Among these methods, adsorption is the most widely used method because of the simplicity of operation, high efficiency and low cost (Li et al., 2013; Rangabhashiyam et al., 2016a; Saranya et al., 2017). The adsorbent materials must have a high specific surface area, many adsorption sites, and chemical stability. Batch reactors were easy to use in the laboratory study, but less convenient for industrial applications. On the other hand, fixed-bed columns were widely used in various chemical industries for their operation. The performance of packed beds is described through the concept of the breakthrough curve. The time for breakthrough appearance and the shape of the breakthrough curve are very important characteristics for determining the operation and the dynamic response of an adsorption column (Chen and Wang, 2000).

In the present study, $\mathrm{Ag}_{2} \mathrm{O} / \mathrm{SD} \mathrm{NC}$ was employed as a lowcost and efficient nano adsorbent material for removal of $\mathrm{Cr}(\mathrm{VI})$ ions from aqueous solutions. Chemical modification can improve the sorption capability of wood sawdust for removal of any toxic materials from aqueous solutions (Moafi et al., 2016). Continuous adsorption experiments were performed to see the effect of influencing parameters such as feed solution $\mathrm{pH}$, flow rate, initial concentration of $\mathrm{Cr}(\mathrm{VI})$ solution and bed height of adsorbent on $\mathrm{Cr}$ (VI) removal. Mathematical models for fixed-bed adsorption systems, including Thomas, Adams-Bohart and Bed depth 
service time (BDST) have been employed for determination of the column performance. Analysis of $\mathrm{Cr}(\mathrm{VI})$ was carried out spectrophotometerically using 1, 5-diphenyl-carbazide (DPC) reagent (Carrington et al., 2007; Gajghate et al., 1992). DPC reagent dissolved in acetone solvent and sulfuric acid $(\mathrm{pH}=2)$ and the intense adsorption of the redviolet colored complex formed $\left(\lambda_{\max }=540 \mathrm{~nm}\right)$. A calibration curve based on Beer' Lambert law was employed for the analysis of unadsorbed $\mathrm{Cr}(\mathrm{VI})$ in supernatants.

\section{Experimental}

\subsection{Materials and Methods}

All chemicals used were of analytical grade (AR) and were prepared in distilled water. Sawdust samples (SD) from dicer were obtained from a local carpentry workshop. Silver nitrate $\left(\mathrm{AgNO}_{3}\right)$, sodium hydroxide $(\mathrm{NaOH})$, Potassium dichromate $\left(\mathrm{K}_{2} \mathrm{Cr}_{2} \mathrm{O}_{7}\right)$, 1,5-di-phenylcarbazide reagent was obtained from Merck. A column made of Pyrex glass tube having an inner diameter of $1.0 \mathrm{~cm}$ and height of $40 \mathrm{~cm}$ was used for adsorption experiments in the fixed bed column system. A Metrohm pH meter (Model 827) with a combined double junction glass electrode, calibrated against two standard buffer solutions at $\mathrm{pH} 4.0$ and 7.0, was used for $\mathrm{pH}$ measurements. The $\mathrm{pH}$ adjustments of the test solutions were made using either dilute $\mathrm{NaOH}$ or $\mathrm{HCl}$ solutions. A single beam Perkin-Elmer UV-Vis spectrophotometer with a $1 \mathrm{~cm}$ cell was used for measuring all of the adsorption data. Philips PW X-ray diffractometer at a voltage of $40 \mathrm{kV}$ and a current of 100 $\mathrm{mA}$ coupled with monochromatic $\mathrm{Cu}-\mathrm{K}_{\alpha}$ radiation $(\lambda=1.5405 \AA)$, with a scan rate of $2 \% / m i n$ for $2 \theta$ between 10 and 70 degrees. Scanning electron microscopy (SEM) (LEO 1430VP) was used to characterize the surface morphology of the adsorbent. The infrared spectra $\left(400-4000 \mathrm{~cm}^{-1}\right)$ of the samples were recorded on an alpha FT-IR (2011 Bruker Optic $\mathrm{GmbH}$ ) instrument.

\subsection{Preparation of adsorbent}

$5.0 \mathrm{~g}$ of sawdust was added to $50 \mathrm{~mL}$ of silver nitrate $(0.20$ M) solution and then $50 \mathrm{~mL}$ of sodium hydroxide $(0.40 \mathrm{M})$ was added slowly and drop wise, while the solution was constantly stirred with a magnetic stirrer, until the solution had the consistency of a brown-black colloidal suspension. After addition of $\mathrm{NaOH}$ solution, the mixture was heated for 2 hours at temperature about $70-80^{\circ} \mathrm{C}$ accompanied by stirring using a magnetic stirrer. Then, the solution allowed cooling gradually. The coated particles separated from the solution by filtering, washed with distilled water and dried in oven at $90-100{ }^{\circ} \mathrm{C}$ until constant weight.

\subsection{Adsorption studies}

Continuous flow adsorption studies were conducted in a column made of Pyrex glass tube. Before pouring the absorbent into column, a layer of glass wool was placed to prevent loss of adsorbent. A stock $\mathrm{Cr}$ (VI) solution (200 $\mathrm{mg} / \mathrm{L}$ ) was prepared in distilled water using $\mathrm{K}_{2} \mathrm{Cr}_{2} \mathrm{O}$. All working solutions were prepared by diluting the stock solution with distilled water. The feed solution was poured from above at a desired flow rate. To determine the influences of initial chromium (VI) concentration, flow rate and bed height, different experiments were performed. The plan of the experiments is given in Table 1.

The breakpoint time is defined as the time of adsorption when the outlet Chromium (VI) concentration from the column was about $1-5 \%$ of the inlet concentration.

Table 1. Experimental plan for adsorption of $\mathrm{Cr}$ (VI) onto $\mathrm{Ag}_{2} \mathrm{O} / \mathrm{SD} \mathrm{NC}$

\begin{tabular}{ccc}
\hline \multicolumn{3}{c}{ Parameters } \\
\hline $\begin{array}{c}\text { Initial Cr (VI) } \\
\text { concentration } \\
\text { (mg/L) }\end{array}$ & $\begin{array}{c}\text { Bed height } \\
(\mathbf{c m})\end{array}$ & $\begin{array}{c}\text { Flow rate } \\
(\mathbf{m L} / \mathbf{m i n})\end{array}$ \\
\hline 25 & 4 & 2 \\
50 & 4 & 2 \\
100 & 4 & 2 \\
25 & 8 & 2 \\
25 & 12 & 2 \\
25 & 4 & 1 \\
25 & 4 & 5 \\
\hline
\end{tabular}

The total stoichiometric quantity of adsorbed $\mathrm{Cr}(\mathrm{VI})$ (qtotal) in the column for a given inlet $\mathrm{Cr}$ (VI) concentration and flow rate is calculated using Eq. 1 (Rangabhashiyam et al., 2016b).

$$
q_{\text {total }}=\frac{F A_{c}}{1000}=\frac{F}{1000} \int_{t=0}^{t=t_{\text {tot }}} C_{a d} d t
$$

The area under the breakthrough curve $\left(A_{c}\right)$ is obtained by plotting the adsorbed concentration $\left(C_{a d}\right)$ versus time $(t)$. The total amount of $\mathrm{Cr}(\mathrm{VI})$ sent to column $\left(\mathrm{m}_{\mathrm{t}}\right)$ was calculated using Eq. 2.

$$
m_{t}=\frac{C_{a d} F t_{t}}{1000}
$$

Where, $t_{\mathrm{t}}$ is the time equivalent to the total stoichiometric capacity of the column which is defined by Eq. 3 .

$$
t_{t}=\frac{q_{t}}{m_{t}} t_{f}
$$

The removal percentage (S) was calculated using Eq. 4 (Gupta and Babu, 2010).

$$
S(\%)=\frac{q_{t}}{m_{t}} \times 100
$$

The regeneration efficiency (RE \%) was calculated using Eq. 5.

$$
\% R E=\frac{q_{r e g}}{q_{\text {org }}} \times 100
$$

Where, $q_{\text {reg }}$ is the adsorptive capacity of the regenerated column and $q_{\text {org }}$ is the sorption capacity of the original column (Ansari et al., 2013).

\subsection{Mathematical modeling of breakthrough curves (BTC)}

\subsubsection{Thomas kinetics model}


The data obtained in column in continuous mode studies was used to calculate the maximum concentration of $\mathrm{Cr}(\mathrm{VI})$ on adsorbent and the adsorption rate constant using the kinetic model developed by Thomas. The Thomas solution is one of the most general methods that is widely used for column performance determination. The expression by Thomas for an adsorption column is given as follows (Karimi et al., 2012; Han et al., 2006).

$$
\frac{C_{t}}{C_{0}}=\frac{1}{1+\exp \left[\frac{K_{T h}}{F}\left(q_{0} \cdot x-C_{0} \cdot V_{e f f}\right)\right]}
$$

The linearization of Eq. 6 yields:

$$
\ln \left(\frac{C_{0}}{C_{t}}-1\right)=\frac{K_{T h} \cdot q_{0} \cdot x}{F}-K_{T h} \cdot C_{0} \cdot t
$$

From the linear dependence of $\ln \left(\frac{C_{0}}{C_{t}}-1\right)$ versus $\mathrm{V}$, the adsorption removal capacity $\left(\mathrm{q}_{0}\right)$ and rate constant ( $\mathrm{K}_{\mathrm{Th}}$ ) can be determined (Hasanzadeh et al., 2016; Rangabhashiyam et al., 2016c).

\subsubsection{Bohart-Adams model}

The Adamas-Bohart model is based on the surface reaction theory that established a fundamental equation for describing the relationship between $C_{t} / C_{0}$ and $t$. The adsorption rate is controlled by external mass transfer and equilibrium is not instantaneous (Bohart and Adams, 1920). Generally, it is descriptive to analyze the initial part of a breakthrough curve $\left(C_{t} / C_{0}<0.5\right)$ (Bhaumik et al., 2013; Wang et al., 2015). The expression is as follows:

$$
\ln \left(\frac{C_{t}}{C_{0}}\right)=K_{A B} C_{0} t-K_{A B} N_{0}\left(\frac{Z}{U_{0}}\right)
$$

Where $U_{0}$ is the superficial velocity $(\mathrm{cm} / \mathrm{min})$ defined as the ratio of the volumetric flow rate $q\left(\mathrm{~cm}^{3} / \mathrm{min}\right)$ to the crosssectional area of the $A$ bed $\left(\mathrm{cm}^{2}\right)$.

\subsubsection{Bed-depth service time model (BDST)}

It is generally accepted that the BDST model offers the simplest approach and rapid prediction of adsorbent design and column performance. The BDST is a model for predicting the relationship between bed depths $(z)$ and service time $(t)$. This BDST model was focused on the estimation of characteristic parameters such as the maximum adsorption capacity ( $\left.\mathrm{N}_{0}\right)$ and kinetic constant $\left(K_{a}\right)$. This model assumes that the adsorption rate is proportional to the residual capacity of the sorbent and the concentration of the sorbing species. The service time was related to process conditions and operating parameters as (Negrea et al., 2011):

$$
\ln \left(\frac{C_{0}}{C_{b}}-1\right)=\ln \left(\exp \left(\frac{K_{a} \cdot Z \cdot N_{0}}{F}\right)-1\right)-K_{a} C_{0} t_{B}
$$

A linear relationship between bed-depth and service time may be given by Eq. 10 (Rangabhashiyam et al., 2016 b).

$$
t_{B}=\frac{N_{0}}{C_{0} U_{0}} Z-\frac{1}{K_{a} C_{0}} \ln \left(\frac{C_{0}}{C_{b}}-1\right)
$$

Thus, NO and Ka can be evaluated from the slope $\left(\frac{N_{0}}{C_{0} U_{0}}\right)$ and the intercept $\left(\frac{1}{K_{a} C_{0}} \ln \left(\frac{C_{0}}{C_{b}}-1\right)\right)$ of the plot of tB versus $Z$, respectively.

\section{Results and discussion}

\subsection{Characterization of the adsorbent}

\subsubsection{X-ray Diffraction (XRD) Analysis}

The XRD patterns of $\mathrm{Ag}_{2} \mathrm{O}$ nanoparticles, untreated Sawdust and $\mathrm{Ag}_{2} \mathrm{O} /$ Sawdust $\mathrm{NC}$ before $\mathrm{Cr}(\mathrm{VI})$ adsorption prepared via a chemical precipitation method, are shown in Figure 1. The XRD pattern of $\mathrm{Ag}_{2} \mathrm{O} N P s$ and sawdust substrate are presented in the Figure $1 a, 1 b$, respectively. In Figure $1 \mathrm{a}$, the bulk of the X-ray signal originated just from the untreated sawdust substrate in $2 \theta=23^{\circ}$. The XRD pattern for the $\mathrm{Ag}_{2} \mathrm{O}$ nanoparticles (Figure $1 \mathrm{~b}$ ) had shown reflections and planes at $2 \theta=32.94^{\circ}(111), 38.22^{\circ}(200)$, $55.12^{\circ}(311)$ and $65.70^{\circ}$ (222) with cubic system and confirms that $\mathrm{Ag}_{2} \mathrm{O}$ NPs was synthesized properly. The characteristic peaks ascertained from the XRD pattern of untreated $\mathrm{Ag}_{2} \mathrm{O} / \mathrm{SD} \mathrm{NC}$ (Figure 1c) indicates that both silver and silver oxide nanoparticles are presented in the prepared nanocomposite (Sullivan et al., 2013; Moafi et al., 2016). It seems that some silver nanoparticles have also been produced in the course of synthesis of $\mathrm{Ag}_{2} \mathrm{O} / \mathrm{SD} \mathrm{NC}$ due to the presence of some reductive functional groups in the sawdust. The reflections observed at $2 \theta=37.90^{\circ}(111)$, $43.90^{\circ}(200)$ and $64.18^{\circ}(220)$ are related to the facecentered cubic (FCC) structure of silver oxide and metallic silver particle with the (111) reflection intensified considerably, in the presence of sawdust (Yang et al., 2004; Janardhanan et al., 2009).

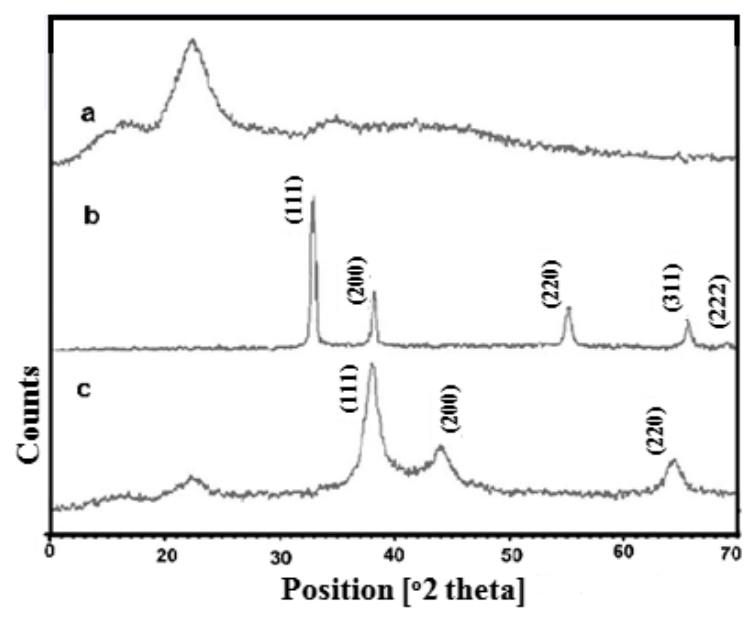

Figure 1. XRD patterns of a) Untreated Sawdust, b) $\mathrm{Ag}_{2} \mathrm{O}$ nanoparticles and c) $\mathrm{Ag}_{2} \mathrm{O}$-coated sawdust 


\subsubsection{Scanning Electron Microscopy (SEM) Analysis}

SEM analysis was performed for characterizing of the surface morphology and particle sizes of the synthesized adsorbent $\left(\mathrm{Ag}_{2} \mathrm{O} / \mathrm{SD} \mathrm{NC}\right)$. SEM micrographs of the samples (untreated Sawdust, $\mathrm{Ag}_{2} \mathrm{O} / \mathrm{SD} \mathrm{NC}$ before and after $\mathrm{Cr}$ (VI) adsorption) are represented in Figure 2 . It is evident that sawdust is a smooth and layered material without any pores (Figures 2a). In Figure 2b, the surface morphology of the chemically modified sawdust with silver oxide or silver NPs before $\mathrm{Cr}(\mathrm{VI})$ adsorption possessing a large amount of tiny particles with various sizes (53-65 $\mathrm{nm}$ ) has been represented. An internal surface and pores are necessary for efficient biosorption (Rangabhashiyam et al., 2014). Figure 2c shows the SEM image of modified sawdust with $\mathrm{Ag}_{2} \mathrm{O}$ NPs after adsorption of $\mathrm{Cr}(\mathrm{VI})$. SEM images were shown that the most of $\mathrm{Ag}_{2} \mathrm{O}$ particles are irregularly shaped and relatively spherical with dimensions less than $160 \mathrm{~nm}$. It can clearly be seen that the surfaces of adsorbent were covered with the fine particles of $\mathrm{Cr}(\mathrm{VI})$ and the bulk particles are separated. Moreover, the new nano-sized formed particles on the surface of the modified adsorbent $\left(\mathrm{Ag}_{2} \mathrm{O} / \mathrm{SD}\right)$ explains the high specific pore surface area and the enhanced sorption capacity of the modified adsorbent (Moafi et al., 2016).

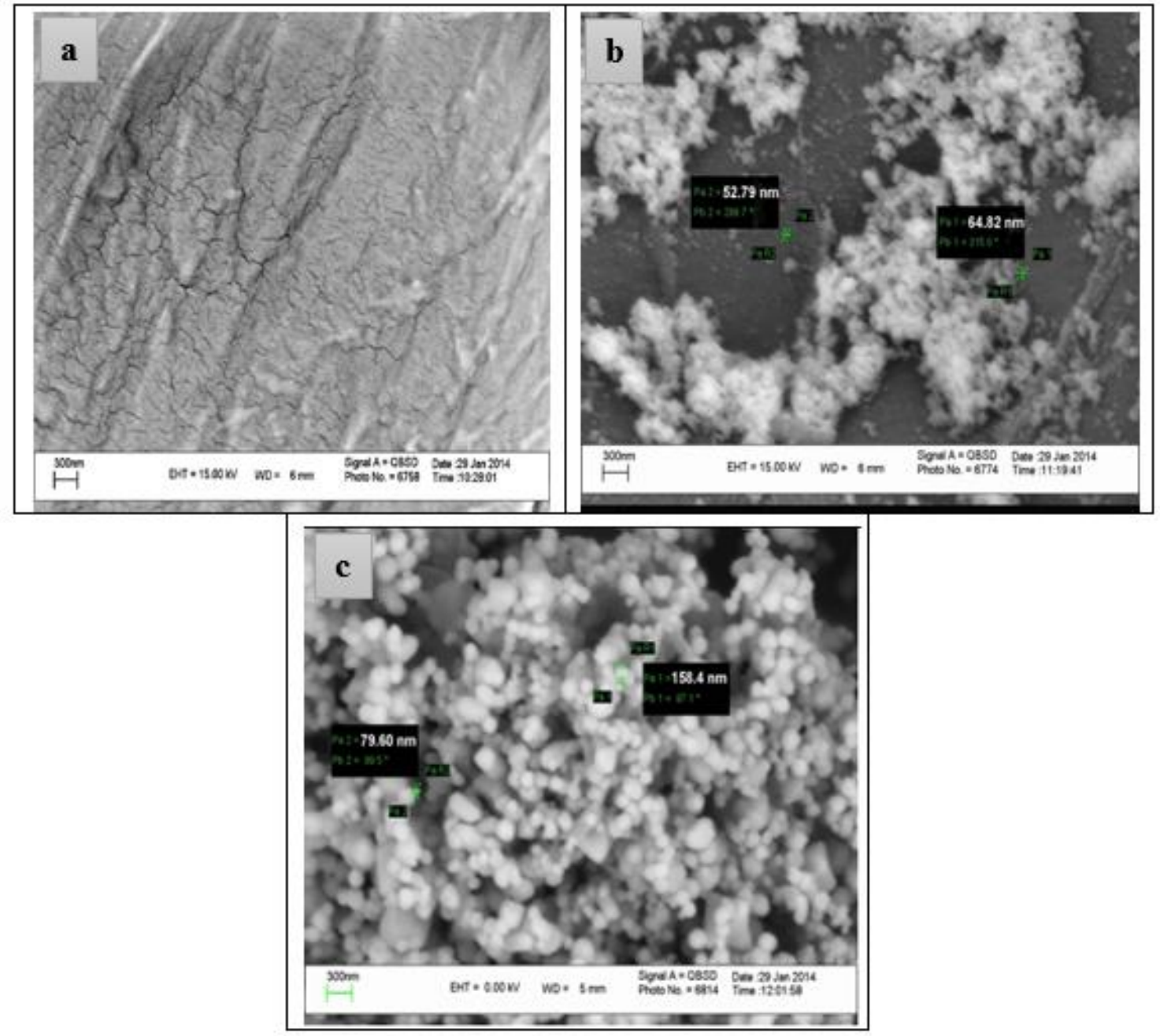

Figure 2. SEM micrograph of a) Untreated Sawdust b and c) $\mathrm{Ag}_{2} \mathrm{O} /$ Sawdust Nanocomposite before and after $\mathrm{Cr}(\mathrm{VI})$ Adsorption, respectively

\subsubsection{Fourier Transform Infrared Spectroscopy (FT-IR) spectroscopy study}

The FTIR spectra of $\mathrm{Ag}_{2} \mathrm{O} / \mathrm{SD}$ NC before and after adsorption are shown in Figure 3. FTIR spectrum analysis confirms that the silver oxide nanoparticles are dispersed onto the sawdust. Figure 3a shows the FT-IR spectra of $\mathrm{Ag}_{2} \mathrm{O} / \mathrm{SD}$ NC. Sawdust bed in nanocomposite has a fiber structure and its main component is cellulose, which has a straight chain structure and large molecular mass. The adsorption peak at $3417 \mathrm{~cm}^{-1}$ indicates the hydroxyl groups and the contribution from $\mathrm{C}-\mathrm{H}$ stretching, respectively
(Nakkeeran et al., 2016a). The band at $2354 \mathrm{~cm}^{-1}$ is assigned to stretching vibrations of $\mathrm{N}-\mathrm{H}$ or $\mathrm{C}=\mathrm{O}$ groups probably due to amines and ketones, $1642 \mathrm{~cm}^{-1}$ is an indication of $\mathrm{COO}, \mathrm{C}=\mathrm{O}$, and can also indicate the bending vibration of adsorbed water (Rangabhashiyam., 2015a), $1030 \mathrm{~cm}^{-1}$ is stretching vibration of $\mathrm{C}-\mathrm{O}-\mathrm{C}$ and $\mathrm{O}-\mathrm{H}$ of polysaccharides in sawdust (Gode et al., 2008). The absorption peak at $1416 \mathrm{~cm}^{-1}$ could be assigned to $\mathrm{CO}_{2}$ stretching vibration (carbon dioxide from the atmosphere, perhaps due to the mesoporous nature of $\mathrm{Ag}_{2} \mathrm{O}$ nanomaterials). The Ag-O-Ag stretching vibration band could be appeared at around of $607 \mathrm{~cm}^{-1}$ which is covered 
due to the overspread of spectra in the region 400-500 $\mathrm{cm}^{-1}$ (Rahman et al., 2013). FT-IR spectra of $\mathrm{Ag}_{2} \mathrm{O} / \mathrm{SD} \mathrm{NC}$ after adsorption of $\mathrm{Cr}(\mathrm{VI})$ are shown in Figure $4 \mathrm{~b}$. Two new peaks were observed in the FTIR spectra of $\mathrm{Cr}(\mathrm{VI})$ - loaded sorbents ( 807 and $900 \mathrm{~cm}-1$ ) attributed to $\mathrm{Cr}=\mathrm{O}$ and $\mathrm{Cr}-\mathrm{O}$ bonds of $\mathrm{HCrO} 4-$, which suggests that $\mathrm{Cr}(\mathrm{VI})$ was adsorbed on the surface of Ag2O/SD nanocomposite (Deng and Bai, 2004; Kyzas et al., 2009). The uptake of $\mathrm{Cr}(\mathrm{VI})$ ions using some bioadsorbents has also been well evidenced employing EDX technique (Nakkeeran et al., 2016b; Rangabhashiyam and Selvaraju., 2015b)

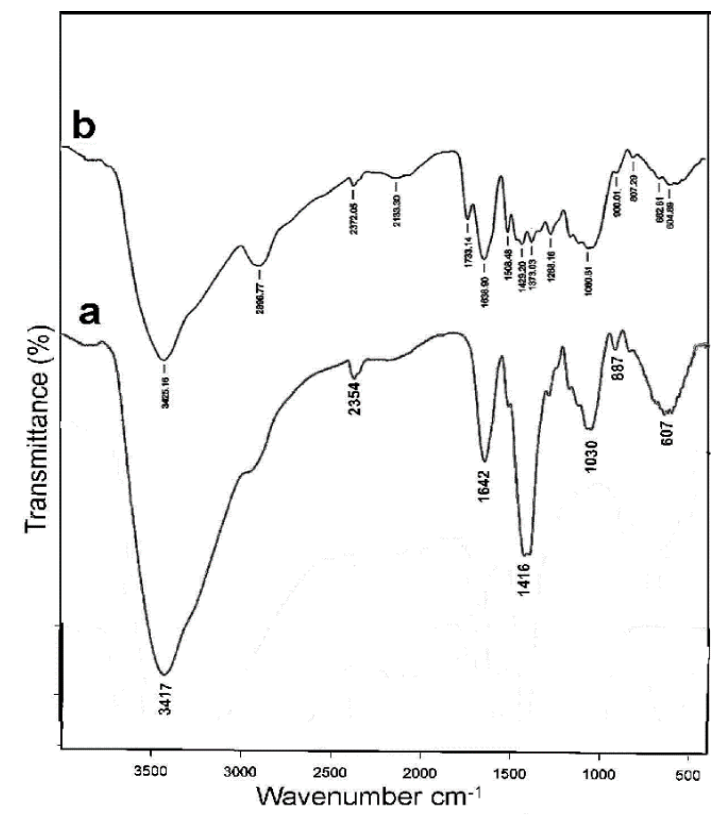

Figure 3. FT-IR spectra of a) $\mathrm{Ag}_{2} \mathrm{O} / \mathrm{SD} \mathrm{NC}$ before $\mathrm{Cr}(\mathrm{VI})$ adsorption, b) $\mathrm{Ag}_{2} \mathrm{O} / \mathrm{SD} \mathrm{NC}$ after $\mathrm{Cr}(\mathrm{VI})$ adsorption.

\subsection{Effect of Operational Parameters}

\subsubsection{The effect of initial solution $\mathrm{pH}$}

The $\mathrm{pH}$ of feed solution is an important controlling parameter in the $\mathrm{Cr}(\mathrm{VI})$ adsorption process and thus the role of hydrogen ion concentration was examined from solutions at different $\mathrm{pH}$, covering about 2.0, 6.0 and 10.0. Figure 4 shows the effect of $\mathrm{pH}$ values on adsorption of $\mathrm{Cr}$ (VI) ions onto $\mathrm{Ag}_{2} \mathrm{O} /$ Sawdust $\mathrm{NC}$ using a plot of dimensionless concentration $\left(C_{t} / C_{0}\right)$ versus effluent volume (V). The initial $\mathrm{pH}$ of the adsorption medium relates to the adsorption mechanisms onto the adsorbent surface from water and reflects the nature of the physicochemical interaction of the species in solution and the adsorptive sites of adsorbent (Gao et al., 2009). There are several forms of $\mathrm{Cr}(\mathrm{VI})$ ions existing in the solution; they are chromate $\left(\mathrm{CrO}_{4}{ }^{2-}\right)$, dichromate $\left(\mathrm{Cr}_{2} \mathrm{O}_{7}{ }^{2-}\right)$ and hydrogen chromate $\left(\mathrm{HCrO}_{4}^{-}\right)$. These ions forms are related to the solution $\mathrm{pH}$ and total $\mathrm{Cr}$ (VI) concentration (Weckhuysen and Wachs, 1996; Rangabhashiyam and Selvaraju, 2015c). At $\mathrm{pH}$ lower than $6.8, \mathrm{HCrO}_{4}{ }^{-}$is the conquering species, and at $\mathrm{pH}$ above 6.8 only $\mathrm{CrO}_{4}{ }^{2-}$ is the most prominent. When the $\mathrm{pH}$ is low, they could be adsorbed by positively charged through electrostatic attraction (Li et al., 2013; Rangabhashiyam, 2016d).

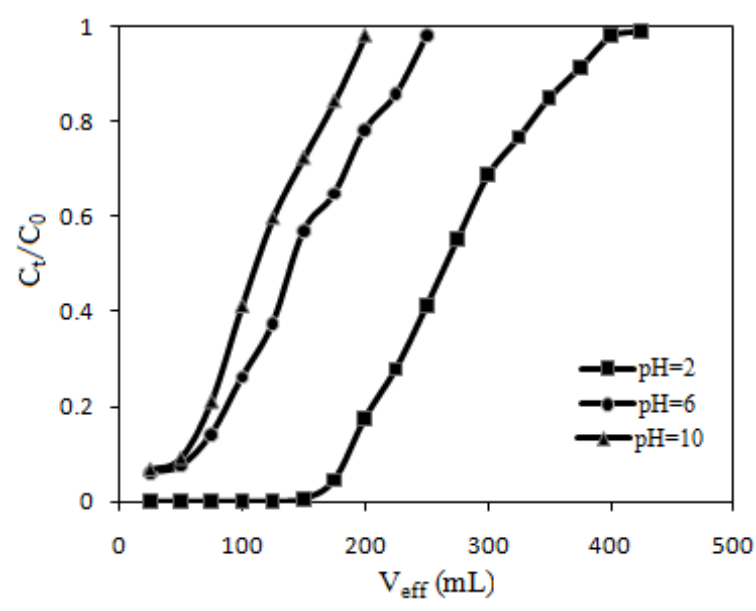

Figure 4. Effect of solution $\mathrm{pH}$ on BTC $\left(\mathrm{C}_{0}=25 \mathrm{mg} \mathrm{L}^{-1}\right.$, F.r. $=$

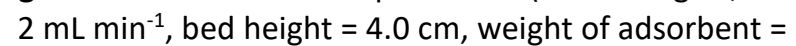

$$
0.50 \mathrm{~g})
$$

As shown, the adsorption of $\mathrm{Cr}(\mathrm{VI})$ ions onto $\mathrm{Ag}_{2} \mathrm{O} / \mathrm{SD} \mathrm{NC}$ greatly affects the $\mathrm{pH}$. The highest bed capacity and the longest breakthrough time were obtained at low $\mathrm{pH}$ value $(\mathrm{pH}=2)$.

\subsubsection{The effect of flow rate}

The effect of flow rate on the performance of the column was studied at three different flow rates of 1,2 and 5 $\mathrm{mL} / \mathrm{min}$. During the experiments the bed height and initial concentration of feed was maintained at constant values of $4 \mathrm{~cm}$ and $25 \mathrm{mg} / \mathrm{L}$, respectively. The breakthrough curves are depicted in Figure 5. The effects of flow rate on adsorption results can be illustrated according to mass transfer concepts.

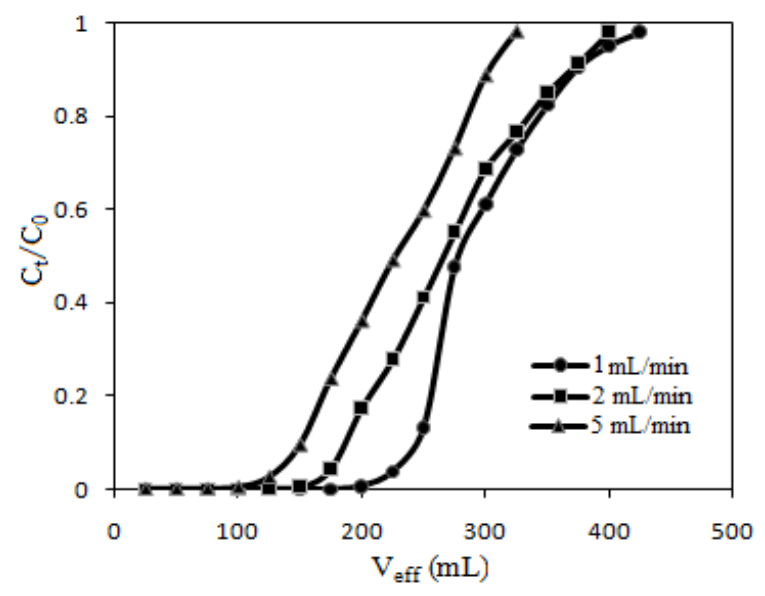

Figure 5. Effect of Flow rate on BTC ( $\mathrm{C}_{0}=25 \mathrm{mg} / \mathrm{L}, \mathrm{pH}=$ 2.0 , bed height $=4 \mathrm{~cm}(0.50 \mathrm{~g}))$

As it could be expected with increasing of flow rate the contact time of the adsorbent and adsorbate is decreased. Therefore, the breakpoint has occurred sooner at higher flow rate since with increasing the flow rate, the saturation is happening faster too. When the flow rate is increased, the Chromium (VI) ions do not have enough time to penetrate and diffuse deeply into the pores. Therefore, equilibrium does not take place, and lower adsorption capacity might be achieved at higher flow rate of inlet 
(Ansari et al., 2013; Karimi et al., 2012). As the data show (Figure 5), the breakthrough time decreased from $125 \mathrm{~min}$ to $75 \mathrm{~min}$ when the flow rate changed from 1 to $5 \mathrm{~mL} / \mathrm{min}$. The adsorption capacity was also decreased from 13.6 to $10.7 \mathrm{mg} / \mathrm{g}$. However, as indicated the same sorption capacity was observed for both 2 and $5 \mathrm{~mL} / \mathrm{min}$ flow rates. Then Flow rate of $2 \mathrm{~mL} / \mathrm{min}$ was selected as the optimum flow rate for further studies.

\subsubsection{Effect of influent $\mathrm{Cr}(\mathrm{VI})$ concentration}

To evaluate the effect of $\mathrm{Cr}(\mathrm{VI})$ concentration, the inlet concentration of $\mathrm{Cr}(\mathrm{VI})$ varied from 25 to $100 \mathrm{mg} / \mathrm{L}$ under the same operating conditions of bed depth $(4 \mathrm{~cm}), \mathrm{pH}$ value about 2 and flow rate of $2 \mathrm{~mL} / \mathrm{min}$. Figure 6 depicts three $\mathrm{BTC}$ of $\mathrm{Cr}(\mathrm{VI})$ removal using $\mathrm{Ag}_{2} \mathrm{O} / \mathrm{SD} \mathrm{NC}$ at three different initial $\mathrm{Cr}(\mathrm{VI})$ concentrations.

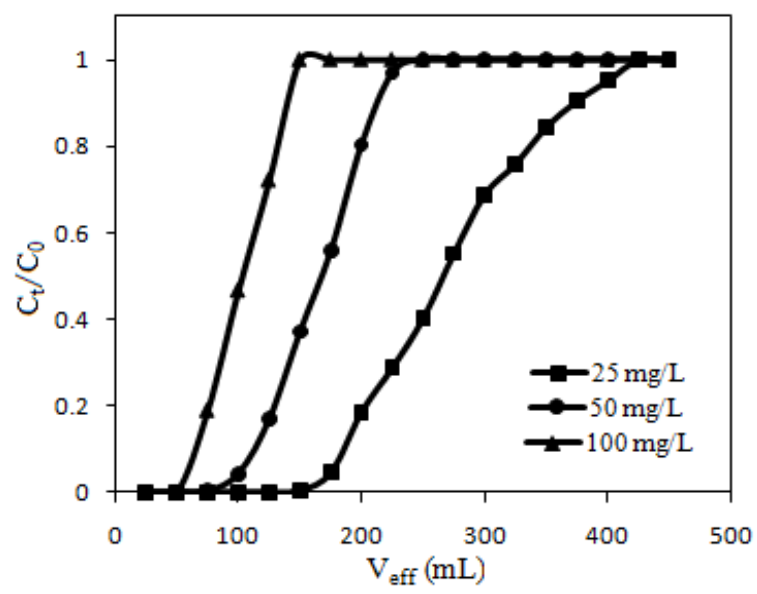

Figure 6. The effect of initial $\mathrm{Cr}(\mathrm{VI})$ concentration on BTC $\left(\mathrm{pH}=2.0\right.$, bed height $\left.=4 \mathrm{~cm}, \mathrm{~F} . \mathrm{r} .=2 \mathrm{~mL} \mathrm{~min}^{1}\right)$

According to the results of Figure 6, the adsorbent gets saturated faster at higher initial concentration and breakthrough time (corresponding to $5 \%$ of influent concentration or $C_{t} / C_{0}=0.05$ ) decreases from about 100 $\mathrm{min}$ to about $35.5 \mathrm{~min}$ as the concentration of chromium (VI) solution increases from 25 to $100 \mathrm{mg} / \mathrm{L}$. As shown (Fig. 6), more volumes of $\mathrm{Cr}(\mathrm{VI})$ polluted solution can be cleaned at lower concentrations, although some gradual increase was observed in the adsorption capacity of columns increased with increase in inlet initial concentration. Maximum bed capacities at 25, 50 and $100 \mathrm{mg} / \mathrm{L}$ of $\mathrm{Cr}$ (VI) concentrations were 12.9, 15.2 and $15.7 \mathrm{mg} / \mathrm{g}$ respectively. At lower inlet $\mathrm{Cr}(\mathrm{VI})$ concentration, BTC was dispersed and breakthrough occurred slowly. As inlet concentration increased, sharper BTC was obtained. These results demonstrate that the change of concentration gradient affects the saturation rate and breakthrough time.

\subsubsection{Effect of column bed depth}

The other factor that has the greatest effect on metal uptake capacity in a packed bed column is the height of adsorbent inside the column. To produce different bed heights, $0.50,1.0$, and $1.50 \mathrm{~g}$ of the $\mathrm{Ag}_{2} \mathrm{O} / \mathrm{SD} \mathrm{NC}$ were added to yield 4,8 , and $12 \mathrm{~cm}$ height, respectively. During the experiments the flow rate and solution concentration were maintained at constant values of $2 \mathrm{~mL} / \mathrm{min}$ and 50 $\mathrm{mg} / \mathrm{L}$, respectively and the solution $\mathrm{pH}$ was kept at a value of about 2. The obtained breakthrough curves for the different bed heights are shown in Figure 7. As can be seen, the breakthrough point occurred more slowly when the bed height changed from 4 to $12 \mathrm{~cm}$. The metal uptake capacity of the $\mathrm{Ag}_{2} \mathrm{O} / \mathrm{SD} \mathrm{NC}$ and metal removal percentage increased with increasing the bed height. On the other hand, more volume of effluent can be treated with longer bed depth. However, the ultimate adsorption capacity of columns increased slightly (from 12.9 to $13.5 \mathrm{mg} / \mathrm{g}$ ) when the bed height changed from 4 to $12 \mathrm{~cm}$ (Zhu et al., 2012; Suganya et al., 2016).

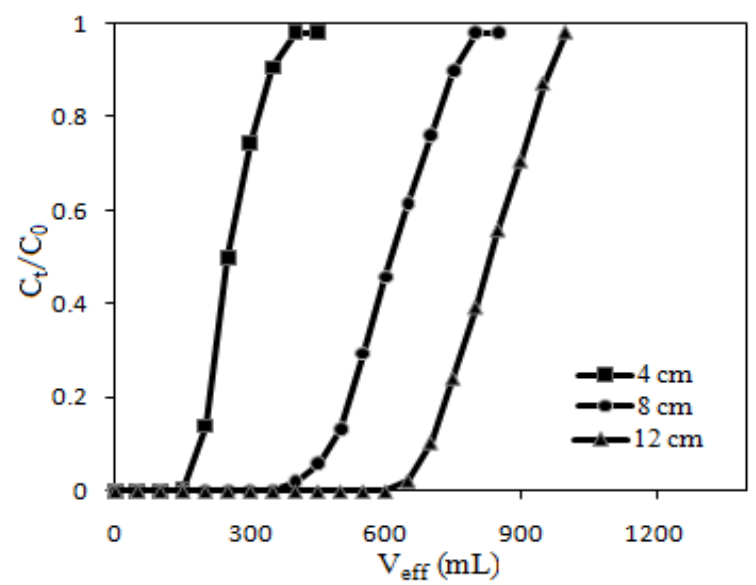

Figure 7. The effect of sorbent bed height on BTC $\left(\mathrm{C}_{0}=25\right.$ $\mathrm{mg} / \mathrm{L}, \mathrm{pH}=2.0, \mathrm{~F} . \mathrm{r} .=2 \mathrm{~mL} \mathrm{~min}^{-1}$ )

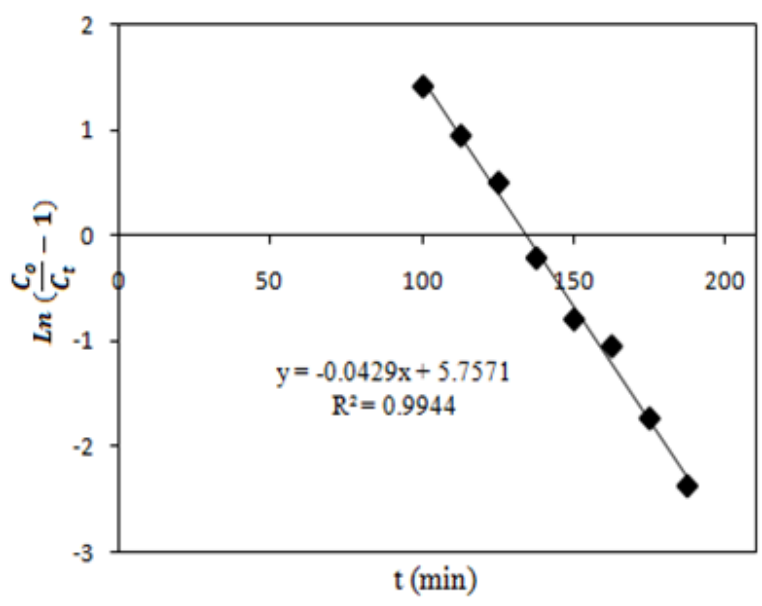

Figure 8. Comparison of the experimental BTC obtained at different initial concentrations of $\mathrm{Cr}(\mathrm{VI})$ according to the Thomas model $\left(\mathrm{pH}=2.0, \mathrm{~F} . \mathrm{r} .=2 \mathrm{~mL} \mathrm{~min}^{-1}\right.$, bed height $=4 \mathrm{~cm}$ )

\subsection{Breakthrough curve modeling}

\subsubsection{The Thomas model}

Thomas model was applied to the experimental data with respect to influent concentration of $\mathrm{Cr}(\mathrm{VI})$, bed mass and flow rate conditions (Figure 8 ). A linear regression analysis was used in each set of data to determine the Thomas model parameters of $\mathrm{q}_{0}$ and $\mathrm{K}_{\mathrm{Th}}$. The determined 
coefficients were also obtained using linear regression analysis according Eq. 7. Based on the regression analysis $\left(R^{2}=0.9944\right)$, the sorption data fit better with the Thomas kinetics model and it can be seen that with the bed mass increasing, the $\mathrm{k}_{\mathrm{TH}}$ values decreased (Rangabhashiyam

Table 2. Thomas and Bohart-Adams model parameters obtained for $\mathrm{Cr}(\mathrm{VI})$ adsorption onto $\mathrm{Ag}_{2} \mathrm{O} / \mathrm{SD} \mathrm{NC}$ under different experimental conditions.

\begin{tabular}{|c|c|c|c|c|c|c|c|}
\hline \multirow[t]{2}{*}{ Parameters } & \multicolumn{4}{|c|}{ Thomas model } & \multicolumn{3}{|c|}{ Bohart-Adams model } \\
\hline & $\begin{array}{c}\mathrm{K}_{\mathrm{Th}} \times 10^{-4}(\mathrm{~mL} / \\
\mathrm{mg} \cdot \mathrm{min})\end{array}$ & $\begin{array}{c}q_{0} \\
(\mathrm{mg} / \mathrm{g})\end{array}$ & $\begin{array}{c}q_{c(\exp )} \\
(\mathrm{mg} / \mathrm{g})\end{array}$ & $\mathbf{R}^{2}$ & $\begin{array}{c}\mathrm{K}_{\mathrm{AB}} \times 10^{-4} \\
(\mathrm{~L} / \mathrm{mg} \cdot \mathrm{min})\end{array}$ & $\begin{array}{c}\mathrm{N}_{0} \times 10^{-2} \\
(\mathrm{mg} / \mathrm{L})\end{array}$ & $\mathbf{R}^{2}$ \\
\hline \multicolumn{8}{|l|}{ Bed mass (g) } \\
\hline 0.5 & 1.72 & 13.41 & 12.90 & 0.9965 & 2.68 & 26.91 & 0.9791 \\
\hline 1 & 1.42 & 15.29 & 13.50 & 0.9714 & 2.68 & 26.04 & 0.9880 \\
\hline 1.5 & 1.46 & 13.73 & 13.80 & 0.9592 & 2.96 & 22.48 & 0.9880 \\
\hline \multicolumn{8}{|c|}{ Initial conc. (mg/L) } \\
\hline 25 & 1.72 & 13.41 & 12.90 & 0.9965 & 2.68 & 26.91 & 0.9791 \\
\hline 50 & 1.65 & 15.62 & 15.20 & 0.9917 & 4.04 & 29.76 & 0.9705 \\
\hline 100 & 1.63 & 16.31 & 15.70 & 0.9914 & 4.73 & 29.77 & 0.9670 \\
\hline \multicolumn{8}{|c|}{ Flow rate $(\mathrm{mL} / \mathrm{min})$} \\
\hline 1 & 2.37 & 7.34 & 13.60 & 0.9713 & 3.00 & 13.59 & 0.9191 \\
\hline 2 & 1.72 & 13.41 & 12.90 & 0.9965 & 2.68 & 26.91 & 0.9791 \\
\hline 5 & 2.45 & 28.01 & 10.70 & 0.9481 & 6.04 & 52.59 & 0.9727 \\
\hline
\end{tabular}

Table 3. Comparison of the column equilibrium adsorption capacity of different adsorbents with $\mathrm{Ag}_{2} \mathrm{O} / \mathrm{SD} \mathrm{NC}$ nanocomposite.

\begin{tabular}{|c|c|c|c|}
\hline Adsorbent & pH & $\begin{array}{c}\text { Capacity } \\
\text { (mg/g) }\end{array}$ & References \\
\hline Ficus auriculata leaves powder & 2.0 & 13.33 & (Rangabhashiyam et al., 2015c) \\
\hline Strychnos nux-vomica shell & 2.0 & 90.9 & (Nakkeeran et al., 2016) \\
\hline poly 3-methyl thiophene / Sawdust & 1.0 & 0.03 & (Ansari and Fallah Delavar, 2010) \\
\hline PPy/Sawdudt & 5.0 & 3.4 & (Ansari and Khoshbakht Fahim, 2007) \\
\hline Sawdudt & $<3$ & 1.0 & (Ansari and Khoshbakht Fahim, 2007) \\
\hline Titanium (IV) oxide nanoparticle & 2.0 & 12.94 & (Debnath et al., 2010) \\
\hline $\mathrm{PPy} / \mathrm{Fe}_{3} \mathrm{O}_{4}$ nanocomposite & 2.0 & 230.17 & (Bhaumik et al., 2013) \\
\hline Rice Husk Carbon & 2.0 & 38.1 & (Singh and Singh, 2012) \\
\hline Cetyl tri methyl ammonium & $1.15-1.39$ & 0.366 & (Rajesh et al., 2007) \\
\hline Carbon slurry & 2.08 & 28 & (Gupta et al., 2010) \\
\hline Jute fiber (PANI-jute) & 3.0 & 4.66 & (Kumar and Chakraborty, 2009) \\
\hline Olive oil industry waste & $1-2$ & 3.33 & (Malkoc et al., 2006) \\
\hline Maize corn cob & 2.0 & 0.28 & (Garg et al., 2007) \\
\hline Rice straw & 2.0 & 3.15 & (Gao et al., 2008) \\
\hline Coal & 2.1 & 6.73 & (Gupta et al., 1997) \\
\hline Red mud & 2.0 & 4.36 & (Gupta et al., 2001) \\
\hline Cactus leaves & 2.0 & 7.08 & (Dakiky et al., 2002) \\
\hline Jatropha oil cake & 2.0 & 0.82 & (Garg et al., 2007) \\
\hline pine leaves & 5.0 & 0.470 & (Aliabadi et al., 2006) \\
\hline Eichhornia crassipes & 2.0 & 5.6 & (Saraswat and Rai., 2010) \\
\hline $\mathrm{Ag}_{2} \mathrm{O} / \mathrm{Sawdust}$ nanocomposite & 2.0 & 13.41 & Current study \\
\hline
\end{tabular}

As shown (Table 2), with increasing the inlet of $\mathrm{Cr}(\mathrm{VI})$ concentration, the value of $q_{0}$ increased and the value of $\mathrm{K}_{\mathrm{Th}}$ is decreased. In addition, although the deviations of experimental and predicted values were quite high, there was a good agreement between the experimental and predicted bed capacities.

To assess the feasibility of the $\mathrm{Ag}_{2} \mathrm{O} / \mathrm{SD}$ nanocomposite, comparison of the adsorption capacity of different low cost and commercially available adsorbents is shown in Table 3. When compared with other adsorbents (Table 3), the et al., 2016c). The correlation coefficients were between 0.976 and 0.994 at the tested initial concentrations. The parameters calculated from the linear plot of Thomas model are summarized in Table 2. 
Bohart model parameters have been summarized in Table 2. As indicated, the fitting breakthrough curves become worse when $C_{t} / C_{0}$ is higher than 0.5 , indicating that the Adams-Bohart model is just appropriate for the initial part of fixed-bed adsorption for removal of $\mathrm{Cr}$ (VI) using $\mathrm{Ag}_{2} \mathrm{O} / \mathrm{SD}$ NC. The values of $\mathrm{R}^{2}$ (from 0.95 to 0.98 ) indicate the relatively high correlation between the fitting data by a nonlinear method and the experimental data. $\mathrm{K}_{\mathrm{AB}}$ increases with an increase in initial concentration and bed mass. Conversely, the values of $\mathrm{N}_{0}$ decrease when there is an increase in bed mass, whereas there is an increase in the value of $\mathrm{N}_{0}$ with initial concentration and flow rate increasing. These results confirm that the sorption kinetics is surmounted by external mass transfer (Bhaumik et al., 2013; Wang et al., 2015).

\subsubsection{Bed depth service time (BDST) model}

The lines of $t-z$ at values of $C_{t} / C_{0}, 0.2,0.4$ and 0.6 are shown in Figure 9.

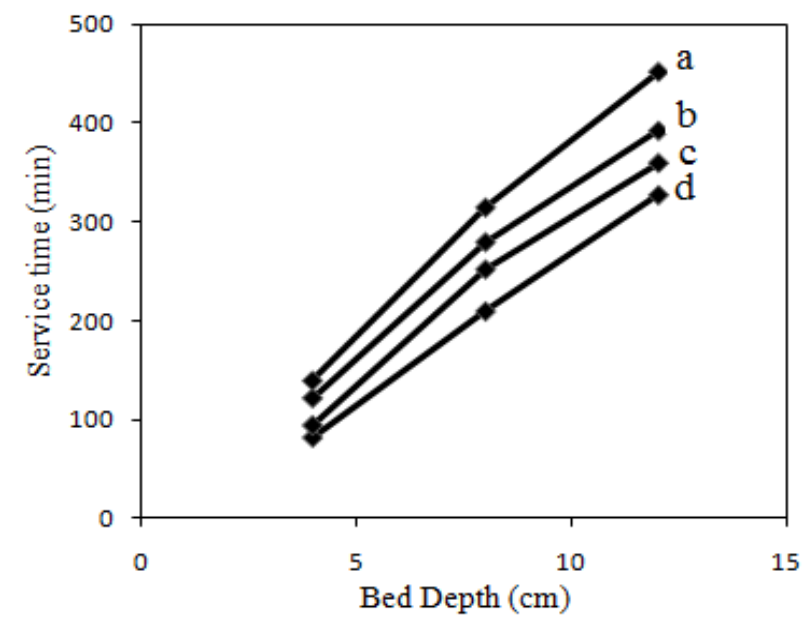

Figure 9. The linear plots of service time $\left(t_{b}\right)$ vs. bed depth at four different breakthrough points $\left((a) C_{t} / C_{0}=0.05\right.$,

(b) $C_{t} / C_{0}=0.2$, (c) $C_{t} / C_{0}=0.4$, (d) $C_{t} / C_{0}=0.6$ )

Table 4. BDST equation parameters obtained from $\mathrm{Cr}$ (VI) sorption onto $\mathrm{Ag}_{2} \mathrm{O} / \mathrm{SD} \mathrm{NC}$ at different breakthrough points

\begin{tabular}{cccc}
\hline $\mathrm{C}_{\mathrm{t}} / \mathrm{C}_{\mathbf{0}}$ & $\begin{array}{c}\boldsymbol{N}_{\mathbf{0}} \\
(\mathbf{m g} / \mathrm{L})\end{array}$ & $\begin{array}{c}\boldsymbol{K}_{\mathrm{a}} \\
\text { (L/mg.min) }\end{array}$ & $\begin{array}{c}\text { Correlation } \\
\text { coefficient }\left(\boldsymbol{R}^{2}\right)\end{array}$ \\
\hline 0.05 & 1612.41 & 0.00307 & 0.9994 \\
0.2 & 1744.03 & 0.00167 & 0.9957 \\
0.4 & 1776.94 & 0.00324 & 0.9908 \\
0.6 & 2053.35 & -0.0168 & 0.9951 \\
\hline
\end{tabular}

From the values of $\mathrm{R}^{2}$, the validity of the BDST model for the present system is confirmed. So, the related constants of BDST according the slopes and intercepts of lines obtained from the linearized form are listed in Table 4. According to Table 4 , as the value of $C_{t} / C_{0}$ increased, the rate constant of $\mathrm{K}_{\mathrm{a}}$ increased and also the adsorption capacity of the bed per unit bed volume $\left(\mathrm{N}_{0}\right)$ increased. Overall, when Ka decreases a progressively with longer $\mathrm{Ct} / \mathrm{CO}$ ratio, this is better and required to avoid breakthrough (Rangabhashiyam et al., 2016c; Cooney, 1999). Pursuant to the regression coefficients ( $R 2>0.99$ ), the match between the experimental data and the model is confirmed.

\subsection{Desorption study}

In this study, various chemicals were tested to recover the adsorbed $\mathrm{Cr}(\mathrm{VI})$ ions from the saturated adsorbent $\left(\mathrm{Ag}_{2} \mathrm{O} / \mathrm{SD} \mathrm{NC}\right)$. Solution of $\mathrm{Cr}(\mathrm{VI})$ with concentration of 25 $\mathrm{mg} / \mathrm{L}$ was passed through the column with a bed depth of $4 \mathrm{~cm}$ and flow rate of $2 \mathrm{~mL} / \mathrm{min}$. The results obtained are summarized in Table 5.

Table 5. Desorption of $\mathrm{Cr}(\mathrm{VI})$ from the used column applying different washing solutions

\begin{tabular}{ccccc}
\hline \multicolumn{5}{c}{ Desorption solution } \\
\hline & $\begin{array}{c}\text { Distilled } \\
\text { water }\end{array}$ & $\begin{array}{c}\mathrm{NaOH} \\
(\mathbf{0 . 0 1} \mathrm{M})\end{array}$ & $\begin{array}{c}\mathrm{HCl} \\
\mathbf{( 0 . 0 1} \mathbf{M})\end{array}$ & $\begin{array}{c}\mathrm{NaCl}(0.01 \\
\mathrm{M})\end{array}$ \\
\cline { 2 - 5 } $\begin{array}{c}\text { Desorption } \\
\%\end{array}$ & $<2$ & $>98.0$ & 0.00 & 2.0 \\
\hline Asthenyyyyyy
\end{tabular}

As the data show, among the different washing solutions used, it was found that desorption is readily achieved with a dilute solution of $\mathrm{NaOH}(0.01 \mathrm{M})$. It was found that the regenerated exhausted column can be used for removal of $\mathrm{Cr}(\mathrm{VI})$ without any measurable loss of its sorption capacity. Sorption/desorption processes were repeated at least for three cycles. It was found that more than $98 \%$ of previously adsorbed $\mathrm{Cr}(\mathrm{VI})$ onto $\mathrm{Ag}_{2} \mathrm{O} / \mathrm{SD} \mathrm{NC}$ can be easily recovered upon treatment with a dilute $\mathrm{NaOH}$ solution (0.01M) without any measurable decay in sorption capacity (Rangabhashiyam et al., 2015d). Therefore, $\mathrm{Ag}_{2} \mathrm{O} / \mathrm{SD} \mathrm{NC}$ can be used for removal of highly toxic $\mathrm{Cr}(\mathrm{VI})$ ions from the related wastewaters very effectively and efficiently. The exhausted columns can also be simply regenerated for reuse employing a dilute $\mathrm{NaOH}$ solution.

\section{Conclusion}

This study shows that $\mathrm{Ag}_{2} \mathrm{O} / \mathrm{SD} \mathrm{NC}$ is an effective and inexpensive adsorbent for $\mathrm{Cr}$ (VI) removal from aqueous solutions. In the fixed-bed column, the adsorption capacity is strongly dependent on the flow rate, $\mathrm{pH}$ of feed solution, bed depth and initial feed concentration. The bed volumes slightly increased as flow rate and initial concentration was decreased. As the flow rate was increased, the BTC became steeper, the break point time and adsorbed $\mathrm{Cr}$ (VI) ion concentration decreased. With an increase in influent $\mathrm{pH}$, the bed volumes treated decreased. The maximum capacity of $\mathrm{Ag}_{2} \mathrm{O} / \mathrm{SD} \mathrm{NC}$ in column investigation was found to be about $13.4 \mathrm{mg} / \mathrm{g}$ under the selected operational conditions (Flow rate $=2 \mathrm{~mL} / \mathrm{min}, \mathrm{C}_{\mathrm{i}}=25 \mathrm{mg} / \mathrm{L}$, bed depth= $4 \mathrm{~cm}$ and $\mathrm{pH}=2$ ). Thomas, Adams-Bohart and BDST model were used in analysis of column performance and the model parameters were evaluated. The Thomas model was found to be in good agreement with experimental data and could be used for prediction of experimental results as well. The Adams-Bohart model parameters confirm that the sorption kinetics is surmounted by external mass transfer. Also BDST model showed a good correlation of breakthrough curves. The regeneration of exhausted nanocomposite adsorbent after adsorption process can be done with $0.01 \mathrm{M} \mathrm{NaOH}$ solution and the regenerated sorbent can be used for adsorption without any loss in its sorption capacity (Reg\% > 95). 


\section{References}

Ansari R. and Fahim N.K. (2007), Application of polypyrrole coated on wood sawdust for removal of $\mathrm{Cr}(\mathrm{VI})$ ion from aqueous solutions, Reactive and Functional Polymers, 67, 367-374.

Ansari R. and Fallah Delavar A. (2010), Removal of $\mathrm{Cr}(\mathrm{VI})$ ions from aqueous solutions Using Poly 3-Methyl Thiophene Conducting Electroactive Polymers, J Polym Environ, 18, 202-207.

Ansari R., Saghanejhad-Tehrani M. and Banimahd-Keivani M. (2013), Application of Polythiophene-Sawdust NanoBiocomposite for Basic Dye Removal Using a Continuous System, Journal of Wood Chemistry and Technology, 33, 1932.

Aliabadi M., Morshedzadeh K. and Soheyli H. (2006), Removal of hexavalent chromium from aqueous solution by lignocellulosic solid wastes, International Journal of Environment Science and Technology, 3, 321-325.

Bayramoglu G. and Arica M.Y. (2011), Synthesis of $\mathrm{Cr}(\mathrm{VI})$ imprinted poly(4-vinyl pyridine-co-hydroxyethyl methacrylate) particles: its adsorption propensity to $\mathrm{Cr}(\mathrm{VI})$, Journal of Hazardous Materials, 187, 213-221.

Badruddoza A.Z.M., Shawon Z.B.Z., Rahman M.T., Hao K.W., Hidajat K. and Uddin M.S. (2013), lonically modified magnetic nanomaterials for arsenic and chromium removal from water, Chemical Engineering Journal, 225, 607-615.

Bohart G.S. and Adams E.Q. (1920), Behavior of charcoal towards chlorine, Journal of the Chemical Society, 42, 523-529.

Bhaumik M., Setshedi K., Maity A. and Onyango S.M. (2013), Cr(VI) removal from water using fixed bed column of polypyrrole/ $\mathrm{Fe}_{3} \mathrm{O}_{4}$ nanocomposite, Separation and Purification Technology, 110, 11-19.

Chen J.P. and Wang X. (2000), Removing copper, zinc and lead ion by granular activated carbon in pretreated fixed bed columns, Separation and Purification Technology, 19, 157-167.

Carrington N.A., Thomas G.H., Rodman D.L., Beach D.B. and Ling X.Z. (2007), Optical determination of $\mathrm{Cr}(\mathrm{VI})$ using regenerable, functionalized sol-gel monoliths, Analytica Chimica Acta, 581, 232-240.

Cooney D.O. (1999), Adsorption design for wastewater treatment, CRC Pres. INC., Boca Raton, Florida, USA, 137-172.

Dakiky M., Khamis M., Manassra A. and Mereb M. (2002), Selective adsorption of chromium (VI) in industrial wastewater using low-cost abundantly available adsorbents, Advances in environmental research, 6, 533-540.

Deng S. and Bai R. (2004), Removal of trivalent and hexavalent chromium with aminated polyacrylonitrile fibers: performance and mechanisms, Water Research, 38, 24242432.

Debnath S., Biswas K. and Ghosh U.C. (2010), Removal of Ni(II) and $\mathrm{Cr}(\mathrm{VI})$ with titanium(IV) oxide nanoparticle agglomerates in fixed-bed columns, Industrial and Engineering Chemistry Research, 49, 2031-2039.

Moafi H.F., Ansari R. and Ostovar F. (2016), $\mathrm{Ag}_{2} \mathrm{O} /$ Sawdust nanocompositeas an efficient adsorbent for removal of hexavalent chromium aqueous solution, Journal of Materials and Environmental Science, 7, 2051-2068.

Gajghate D.G., Saxena E.R. and Aggarwal A.L. (1992), Removal of chromium (VI) as chromium diphenyl carbazide (CDC) complex from aqueous solution by activated carbon, Water, Air, and Soil Pollution, 65, 329-337.
Garg U.K., Kaur M.P., Garg V.K. and Sud D. (2007), Removal of hexavalent chromium from aqueous solution by agricultural waste biomass, Journal of Hazardous Materials, 140, 60-68.

Gao H., Liu Y., Zeng G., Xu W., Li T. and Xia W. (2008), Characterization of $\mathrm{Cr}(\mathrm{VI})$ removal from aqueous solutions by a surplus agricultural waste-rice straw, Journal of Hazardous Materials, 150, 446-452.

Gode F., Atalay E.D. and Pehlivan E. (2008), Removal of $\mathrm{Cr}(\mathrm{VI})$ from aqueous solutions using modified red pine sawdust, Journal of Hazardous Materials, 152, 1201-1207.

Gupta S. and Babu B.V. (2010), Experimental investigations and theoretical modeling aspects in column studies for removal of $\mathrm{Cr}(\mathrm{VI})$ from aqueous solutions using activated Tamarind Seeds, Journal of Water Resource and Protection, 2, 706-716.

Gupta V.K., Srivastava S.K., Mohan D. and Sharma S. (1997), Design parameters for fixed bed reactors of activated carbon developed from fertilizer waste for the removal of some heavy metal ions, Waste management, 17, 517-522.

Gupta V.K, Gupta M. and Sharma S. (2001), Process development for the removal of lead and chromium from aqueous solutions using red mud-an aluminium industry waste, Water research, 35, 1125-1134.

Gupta V.K., Rastogi A. and Nayak A. (2010), Adsorption studies on the removal of hexavalent chromium from aqueous solution using a low cost fertilizer industry waste material, Journal of Colloid and Interface Science, 342, 135-141.

Guan X., Dong H., Ma J. and Lo I.M. (2011), Simultaneous removal of chromium and arsenate from contaminated ground water by ferrous sulfate: Batch uptake behavior, Journal of Environmental Sciences, 23, 372-380.

Han R., Wang Y., Yu W., Zou W., Shi J. and Liu H. (2006), Biosorption of methylene blue from aqueous solution by rice husk in a fixed-bed column, Journal of Hazardous Materials, 141, 713-718.

Hasanzadeh M., Ansari R., and Ostovar F. (2016), Synthesis and application of $\mathrm{CeO} 2 /$ sawdust nanocomposite for removal of As(III) ions from aqueous solutions using a fixed bed column system, Global NEST Journal, 19, 7-16.

Janardhanan R., Karuppaiah M., Hebalkar N. and Rao T.N. (2009), Synthesis and surface chemistry of nano silver particles, Polyhedron, 28, 2522-2530.

Karimi M., Shojaei A., Nematollahzadeh A., J-Abdekhodaie M. (2012), Column study of $\mathrm{Cr}(\mathrm{VI})$ adsorption onto modified silica-polyacrylamide microspheres composite, Chemical Engineering Journal, 210, 280-288.

Kumar P.A. and Chakraborty S. (2009), Fixed-bed column study for hexavalent chromium removal and recovery by short-chain polyaniline synthesized on jute fiber, Journal of Hazardous Materials, 162, 1086-1098.

Kyzas G.Z., Kostoglou M. and Lazaridis N.K. (2009), Copper and $\mathrm{Cr}(\mathrm{VI})$ removal by chitosan derivatives-Equilibrium and kinetic studies, Chemical Engineering Journal, 152, 440-448.

Liu Y., Yuan D., Yan J., Li Q. and Ouyang T. (2011), Electrochemical removal of chromium from aqueous solutions using electrodes of stainless steel nets coated with single wall carbon nanotubes, Journal of Hazardous Materials, 186, 473-480.

Li L., Fan L., Sun M., Qiu H., Li X., Duan H. and Luo Ch. (2013), Adsorbent for chromium removal based on graphene oxide functionalized with magnetic cyclodextrin-chitosan, Colloids and Surfaces B: Biointerfaces, 107, 76- 83. 
Li Y., Gao B., Wu T., Sun D., Li X., Wang B. and Lu F. (2009), Hexavalent chromium removal from aqueous solution by adsorption on aluminum magnesium mixed hydroxide, Water Research, 43, 3067-3075.

Malkoc E., Nuhoglu Y. and Dündar M. (2006), Adsorption of chromium (VI) on pomace-an olive oil industry waste: batch and column studies, Journal of Hazardous Materials, 138, $142-151$.

Malkoc E., Nuhoglu Y. and Abali Y. (2006), Cr(VI) adsorption by waste acorn of Quercus ithaburensis in fixed beds: Prediction of breakthrough curves, Chemical Engineering Journal, 119, 61-68.

Nakkeeran E., Rangabhashiyam S., Giri Nandagopal M.S. and Selvaraju N. (2016, a), Removal of $\mathrm{Cr}(\mathrm{VI})$ from aqueous solution using Strychnos nux-vomica shell as an adsorbent, Desalination and water treatment. 57, 23951-23964.

Nakkeeran E., Saranya N., Giri Nandagopal M.S., Santhiagu A. and Selvaraju N. (2016, b), Hexavalent chromium removal from aqueous solutions by a novel powder prepared from Colocasia esculenta leaves, International Journal of Phytoremediation, 18, 812-821.

Negrea A., Lupa L., Ciopec M. and Negrea P. (2011), Experimental and Modelling Studies on As(III) Removal from Aqueous Medium on Fixed Bed Column, Chemical Bulletin of Politechnica, 56, 89-93.

Rahman M.M., Khan S.B., Asiri A.M. and Al-Sehemi A.G. (2013), Chemical sensor development based on polycrystalline gold electrode embedded low-dimensional $\mathrm{Ag}_{2} \mathrm{O}$ nanoparticles, Electrochimica Acta, 112, 422-430.

Rajesh N., Deepthi B. and Subramaniam A. (2007), Solid phase extraction of chromium (VI) from aqueous solutions by adsorption of its ion-association complex with cetyl tri methyl ammonium bromide on an alumina column, Journal of Hazardous Materials, 144, 464-469.

Rangabhashiyam S., Suganya E., Lity A., Selvaraju N. (2016a), Equilibrium and kinetics studies of hexavalent chromium biosorption on a novel green macroalgae Enteromorpha sp, Research on Chemical Intermediates, 42, 1275-1294.

Rangabhashiyam S. and Selvaraju N. (2015b), Evaluation of the biosorption potential of a novel Caryota urens inflorescence waste biomass for the removal of hexavalent chromium from aqueous solutions, Journal of the Taiwan Institute of Chemical Engineers, 47, 59-70.

Rangabhashiyam S., Giri Nandagopal M.S., Nakkeeran E. and Selvaraju N. (2016c), Adsorption of hexavalent chromium from synthetic and electroplating effluent on chemically modified Swietenia mahagoni shell in a packed bed column, Environmental Monitoring and Assessment, 188, 411.

Rangabhashiyam S., Giri Nandagopal M.S., Nakkeeran E., Keerthi R. and Selvaraju N. (2016d), Use of Box-Behnken design of experiments for the adsorption of chromium using immobilized macroalgae, Desalination and Water Treatment, 57, 26101-26113.

Rangabhashiyam S., Suganya E. and Selvaraju N. (2016e), Packed bed column investigation on hexavalent chromium adsorption using activated carbon prepared from Sweetenia Mahogany fruit shells, Desalination and Water Treatment, 57, 13048-13055.

Rangabhashiyam S. and Selvaraju N. (2015a), Efficacy of unmodified and chemically modified Swietenia mahagoni shells for the removal of hexavalent chromium from simulated wastewater, Journal of Molecular Liquids, 209, 487-497.

Rangabhashiyam S., Selvaraju N., (2015b), Adsorptive remediation of hexavalent chromium from synthetic wastewater by a natural and $\mathrm{ZnCl}_{2}$ activated Sterculia guttata shell, Journal of Molecular Liquids, 207, 39-49

Rangabhashiyam S., Nakkeeran E., Anu N. and Selvaraju N. (2015c), Biosorption potentials of a novel Ficus auriculata leaves powder for the sequestration of hexavalent chromium from aqueous solutions, Research on Chemical Intermediates, 41, 8405-8424.

Rangabhashiyam S., Selvaraju N., Raj Mohan B., Muhammed Anzil P.K., Amith K.D. and Ushakumary E.R (2015d), Hydrous Cerium Oxide Nanoparticles Impregnated Enteromorpha sp. for the Removal of Hexavalent Chromium from Aqueous Solutions, Journal of Environmental Engineering, 142, C4015016.

Saranya N., Nakeeran E., Nandagopal M.G. and Selvaraju N. (2017), Optimization of adsorption process parameters by response surface methodology for hexavalent chromium removal from aqueous solutions using Annona reticulata Linn peel microparticles, Water Science and Technology, 75, 2094-2107.

Sardohan T., Kir E., Gulec A. and Cengeloglu Y. (2010), Removal of $\mathrm{Cr}(\mathrm{III})$ and $\mathrm{Cr}(\mathrm{VI})$ through the plasma modified and unmodified ion-exchange membranes, Separation and Purification Technology. 74, 14-20.

Suganya E., Rangabhashiyam S., Lity A.V. and Selvaraju N. (2016), Removal of hexavalent chromium from aqueous solution by a novel biosorbent Caryota urens seeds: equilibrium and kinetic studies, Desalination and Water Treatment, 57, 23940-23950.

Sullivan K.T., Chunwei W., Piekiel-Nicholas W., Gaskell K. and Zachariah M.R. (2013), Synthesis and reactivity of nano- $\mathrm{Ag}_{2} \mathrm{O}$ as an oxidizer for energetic systems yielding antimicrobial products, Combustion and Flame, 160, 438-446.

Singh S.R. and Singh A.P. (2012), Treatment of Water Containg Chromium (VI) Using Rice Husk Carbon As a New low Cost Adsorbent, International Journal of Environmental Research, 6, 917-924.

Saraswat S. and Rai J.P.N. (2010), Heavy metal adsorption from aqueous solution using Eichhornia crassipes dead biomass, International Journal of Mineral Processing, 94, 203-206.

Wang J., Pan K., He Q. and Cao B. (2013), Polyacrylonitrile/polypyrrole core/shell nanofiber mat for the removal of hexavalent chromium from aqueous solution, Journal of Hazardous Materials, 244, 121-129.

Wang W., Li M. and Zeng Q. (2015), Adsorption of chromium (VI) by strong alkaline anion exchange fiber in a fixed-bed column: Experiments and models fitting and evaluating, Separation and Purification Technology, 149, 16-23.

Weckhuysen B.M. and Wachs I.E. (1996), Surface chemistry and spectroscopy of chromium in inorganic oxides, Chemical Reviews, 96, 3327-3349.

Yang J., Qi L., Zhang D., Ma J. and Cheng H. (2004), DextranControlled Crystallization of Silver Microcrystals with Novel Morphologies, Crystal Growth and Design, 4, 1371-1375.

Zhu J., Wei S., Gu H., Rapole S.B., Wang Q., Luo Z., Haldolaarachchige N., Young D.P. and Guo Z. (2012), One-pot synthesis of magnetic graphene nanocomposites decorated with core@double-shell nanoparticles for fast chromium removal, Environmental science and technology, 46, 977-985. 


\section{Nomenclature}

$A_{c} \quad$ The area under the breakthrough curve

A The cross-sectional area of the bed $\left(\mathrm{cm}^{2}\right)$

$\mathrm{C}_{\mathrm{ad}} \quad$ The adsorbed concentration $(\mathrm{mg} / \mathrm{L}$ )

$\mathrm{C}_{0} \quad$ The concentration of inlet $\mathrm{Cr}(\mathrm{VI})$ at time $\mathrm{t}(\mathrm{mg} / \mathrm{L})$

$\mathrm{C}_{\mathrm{t}} \quad$ The concentration of effluent $\mathrm{Cr}(\mathrm{VI})$ at time $\mathrm{t}(\mathrm{mg} / \mathrm{L})$

$\mathrm{Cb}_{\mathrm{b}} \quad$ The breakthrough $\mathrm{Cr}(\mathrm{VI})$ concentration $(\mathrm{mg} / \mathrm{L})$

F The Flow rate $(\mathrm{mL} / \mathrm{min})$

$\mathrm{K}_{\mathrm{Th}} \quad$ The Thomas kinetics model rate constant $(\mathrm{mL} / \mathrm{min} . \mathrm{mg})$

$\mathrm{K}_{\mathrm{AB}} \quad$ The Bohart-Adams model kinetic constant (L/mg. min)

$\mathrm{Ka} \quad$ The Bed-depth service time model adsorption rate constant ( $\mathrm{L} / \mathrm{mg}$. $\mathrm{min}$ )

$\mathrm{m}_{\mathrm{t}} \quad$ The total amount of $\mathrm{Cr}(\mathrm{VI})$ sent to column (g)

$\mathrm{N}_{0} \quad$ The saturation adsorption capacity per column volume $(\mathrm{mg} / \mathrm{L})$

qtotal The total stoichiometric quantity of adsorbed Chromium (VI) (mg)

$q_{\text {reg }} \quad$ The adsorptive capacity of the regenerated column $(\mathrm{mg} / \mathrm{g})$

$q_{\text {org }} \quad$ The sorption capacity of the original column $(\mathrm{mg} / \mathrm{g})$

qo The equilibrium Chromium (VI) uptake per g of the adsorbent (mg/g)

$\mathrm{S} \quad$ The removal percentage (\%)

$t_{B} \quad$ The service time of Bed-depth service time model (min)

$t_{t} \quad$ The time equivalent to the total stoichiometric capacity of the column ( $\mathrm{min}$ )

$\mathrm{U}_{0} \quad$ The linear flow velocity $(\mathrm{cm} / \mathrm{min})$

$V_{\text {eff }} \quad$ The effluent volume ( $L$ )

$x \quad$ The amount of adsorbent in the column (g)

$\mathrm{Z} \quad$ The bed height of the fix-bed column $(\mathrm{cm})$ 